\title{
The Eosinophil: Physiology and Pathology
}

\author{
Alcibey Alvarado* \\ Internal Medicine and Neumology, Clínica de Diagnóstico Médico. San José, Costa Rica
}

\begin{abstract}
The knowledge of these intriguing cells has gone through various phases since their description. They were originally considered as inflammatory, but protective cells. Subsequently, its potential pathological impact was discovered under various conditions, ranging from antiparasitic and allergic effects to autoimmune, neoplastic, inflammatory and idiopathic disorders. New visions of the molecular basis of the development and traffic of eosinophils and their vigorous participation in the immune regulation circuit define them as very active immune cells, but their ability to invade tissues and their powerful enzyme arsenal place them as effector cells with increased potential inflammatory and cytotoxic. The knowledge of their immunomodulatory activity and their participation in various pathologies has allowed us to design new therapeutic strategies that impact their function in various nosological entities. This monograph aims to update the knowledge of its physiology and associated disorders and diseases.
\end{abstract}

\section{History}

The eosinophils were described in 1846 by Wharton Jones [1] and the name was given by Paul Ehrlich in 1879, who noted his unusual ability to stain with acidophilic stains [2]. Eosin uptake in Wright staining generated its name [3]. When the eosinophils were identified at the end of the $19^{\text {th }}$ century, the only idea was that they were associated with infection and allergic diseases and were considered inflammatory cells [4]. In 1934 Gordon demonstrated that injection of lymphoid nodules from patients with Hodgkin's disease induced a neurotoxic syndrome in experimental animals. That was the first documentation of its pathological potential (eosinophilic neurotoxin).

A second facet of eosinophilic function came to light in 1975 . Two parallel studies showed that they could be considered protective cells, not only because they regulate hypersensitivity reactions but also because they are cytotoxic to parasites in the presence of antibodies [5]. A third aspect was revealed in 1979 when it was shown that the same mediators of eosinophils that are cytotoxic to parasites are also normal mammalian cells [6]. Despite the fact that they were discovered more than 130 years ago, knowledge of the biochemistry and molecular biology of these cells remained static until 1989 when using a purification technique known as "negative selection" it was possible to obtain eosinophils in sufficient numbers and of enough purity to carry out research studies $[7,8]$.

Over the years, knowledge has been increasing significantly. Chu, et al. have suggested a role for eosinophils in the survival of plasma $B$ cells in bone marrow [9]. Its role in maintaining metabolic homeostasis and its potential contribution to protumorigenic and antitumorigenic activity has also been highlighted, despite having no prognostic value in cancer [9-12]. Currently, the presence of eosinophils has been considered a marker of acute GVHD (graft vs host disease) in renal and cardiac transplantation $[13,14]$. The genetic and epigenetic regulation of eosinophils, with special attention to the important roles of the transcription factors GATA- 1 and interleukin (IL)-5, and its therapeutic implications are exploring [15]. Much remains to be discovered. The list of unexplained eosinophilic diseases has increased dramatically in recent years and the role of the eosinophil in these diseases is expected to be unveiled.

\section{Introduction}

These spherical cells, 12-17 $\mu \mathrm{m}$ in diameter, have a bilobed nucleus and pink cytoplasm (acidophilic and affinity for eosin) and are considered non-specific and cytotoxic destructive cells (Figure 1). They originate in bone marrow from pluripotential hematopoietic stem cells, which differ in progenitor cells, which then evolve into a separate mature eosinophilic lineage. Occasionally they may come from thymus and spleen [1]. Once mature, they are released to peripheral blood and their half-life in this compartment is short (around 18 hours), and then be redirected to tissues. Each of these steps is delicately regulated by transcription factors and / or cytokines. There are generally few eosinophils in peripheral blood $\left(<400 / \mathrm{mm}^{3}\right)$ and it is estimated that for every mature circulating eosinophil there are about 300 juvenile cells in reserve in bone marrow and 100-300 eosinophils in tissue (1:100 ratio), mainly in bronchi, intestine, lungs, thymus and uterus. They usually have a circadian rhythm with a value less than 8 a.m. at noon and more than midnight at 4 a.m. Under normal conditions, the clearance occurs in 68 hours, the medullary cycle takes 5 days and its life in tissues seems to be several days [16]. Tissue activation and recruitment occurs in response to appropriate stimuli, most notably IL-5 and eotaxin. There are unclear and controversial aspects regarding their roles in health and disease. For example, the longanchored belief that they promote immunity for helminths has been questioned since animal studies have suggested that eosinophils serve to promote the need and longevity of specific parasites [17]. In asthma, eosinophils contribute to tissue dysfunction and remodeling, however no cell lineage has as a "rationale" for producing pathology and recent discoveries of eosinophilic antimicrobial and antiviral activity suggests

${ }^{\star}$ Correspondence to: Alcibey Alvarado. Clínica de Diagnóstico Médico. Torre Médica. 3 piso. Paseo Colón, San José, Costa Rica, Tel: 50622237134; 50622566439; 50687351858; Fax: 50622216754; E-mail: alcialvagonza@yahoo.com.mx

Key words: eosinophil, parasitic diseases, allergic diseases, eosinophilic infiltration

Received: December 02, 2019; Accepted: January 03, 2020; Published: January 06,2020 


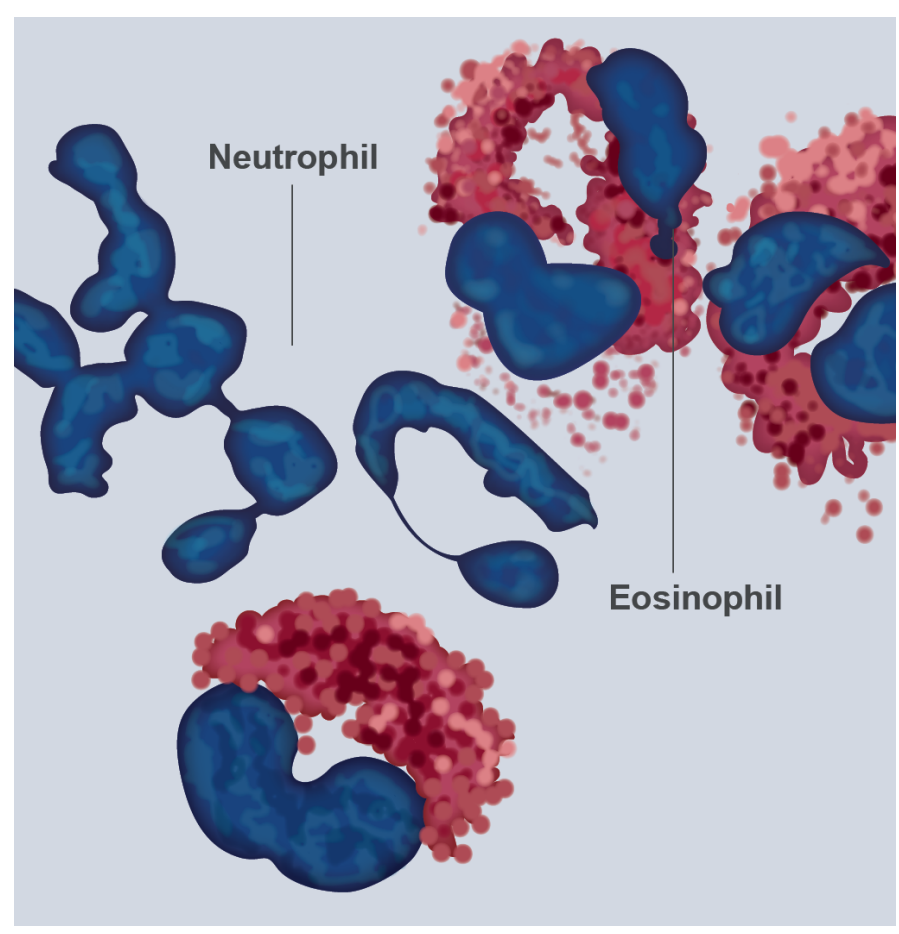

Figure 1. The eosinophils

Modified-Giemsa stained human eosinophils from peripheral blood exhibit characteristic bi-lobed nuclei and large red-stained cytoplasmic secretory granules. The cells with multilobed nuclei and without large granules are neutrophils: original magnification 100X.

that the pathology that originates from eosinophilia dysregulated can be collateral damage related to host defenses [18]. The evolution of knowledge has allowed us to define that these cells are multifunctional in health and disease. Eosinophils express a significant amount of pro-inflammatory cytokines, chemokines and lipid mediators, and express cytokine receptors, immunoglobulins, and complement. They can modify the activity of T cells through the MHC (major histocompatibility complex) class II and co-stimulatory molecules that allow eosinophils to act as antigen presenting cells (APC). They also participate importantly in the innate and adaptive immune response [19]. The advent of clinical studies with monoclonal antibodies that target IL-5 and its receptor has expanded our understanding of eosinophil function.

This monograph examines the latest information on our knowledge of eosinophils in maintaining normal homeostasis and how aberrant or dysregulated eosinophilic function promotes various disease states.

\section{Physiology and biology of Eosinophil}

\section{Eosinophil granule protein}

Human eosinophil granules contain four major proteins: the basic major protein (MBP), the eosinophil cationic protein (ECP), the eosinophil peroxidase (EPO) and the eosinophil-derived neurotoxin $(\mathrm{EDN})$, which, are capable of inducing damage tissue and dysfunction. ECP has been shown to possess antibacterial activity and promote mast cells degranulation. The functional mechanism involves pore formation in target membranes [20]. Other non-cytotoxic activities are suppression of T cell, proliferative activity, immunoglobulins synthesis by B-cells, and stimulation of airway mucus secretion. Eosinophils play a role in protecting against parasitic infections a finding was supported by the direct toxicity of MBP against helminthic worms. The toxic effect is thought to be the result of increased membrane permeability through an interaction of surface charges leading to disturbance of the bilateral lipid surface [19], although the helminths and eosinophils relation is not clear, particularly in how parasites recruit eosinophils and so that [18]. MBP and ECP have bactericidal properties because they have affinity for lipopolysaccharides (LPS), peptidoglycans and agglutinate gram-negative bacteria.

EPO catalyzes the peroxidative oxidation of halides and pseudohalides (thiocyanate) along with hydrogen peroxide concluding with the formation of hypohalous acids, which promotes oxidative stress and cell death by apoptosis and necrosis [21]. EDN can exert cytotoxic effects such as cationic toxin. For example, EDN has the ability to kill newborn larvae of Trichinella spiralis [22].

Eosinophil degranulation does not occur immediately, that is, a degranulation with complete emptying of the protein arsenal, in the presence of a cytolytic assault (real or perceived). It is currently postulated that emptying is more sequentially controlled (piecemeal degranulation) forming vesicles in the cytoplasm with proteins and that they can respond to subsequent stimuli. This concept is important for understanding degranulation in response to cytokines, for example IL-4 [23]. Receptors for cytokines associated with vesicles and granules have been identified and include receptors for IL-4, IL-6, and IL-13, in addition to CCR3. Impacting these traffic lanes with monoclonal antibodies and small molecules awaits future research [24]. The granules also contain deposits of cytokines, enzymes and growth factors. Other primary granules, also contains the proteins of Charcot-Leyden crystals and lipid bodies that are the sites of synthesis of cysteinyl-leukotrienes, thromboxane and prostaglandins.

Charcot-Leyden crystals deserve separate mention because they could be future therapeutic targets in asthma. These needle-shaped crystals $(10-40 \mu)$ are associated with the presence of eosinophils, and can be observed in the sputum of asthmatic patients. Described in 1853 by Charcot, it was originally believed that they were formed by spermine and mucin as precursors [25]. Later it was postulated that it was formed by the phospholipase of the eosinophilic membrane [4]. We currently know that the constituent protein is galectine-10 [26]. Galectins are proteins that bind glycan or lectins with affinity for betagalactose-modified glycoconjugates that is they have a carbohydrate recognition domain. Twenty human galectins generated by the splicing of transcribed messenger pre-RNAs of 11 genes are known. Only galectine-10 crystallizes rapidly and spontaneously under certain conditions, including exocytosis of eosinophils into the extracellular environment. Apparently, the Tyrosine 69 polar residue is vital for crystallization (Tyr 69) [27]. Studies in mice have shown that antibodies against protein dissolve crystals [28].

Dissolution of the crystals could decrease elasticity and improve clearance of impacted mucus in patients with eosinophilic asthma and chronic rhino-sinusitis with nasal polyposis. However, crystals may also come from basophils and medications for clinical use are not yet available in humans.

In addition to the mucolytic effect, the dissolution of the crystals can have an anti-inflammatory effect by blocking the activation of the innate and acquired immune response induced by the crystals. Studies in members of the family camelidae (camels and llamas) with inhaled nanobodies (therapeutic proteins with maximum antibody function, which only have heavy chains), have demonstrated certain suitable characteristics such as small size, thermal stability, high solubility and systemic half-life short [29]. Obviously, future studies in humans are required. Crystal research could help underpin type-2 immunity [30]. 


\section{Markers and cell surface receptors}

Eosinophils express on their surface receptors for ligands that support growth, adhesion, chemotaxis, degranulation, and cell interaction. The $a$-subunit of the IL-5 receptor (IL-5Ra) is the most prominent cytokine receptor associated with eosinophils in humans. Within the adhesion receptors, L-selectin and P-selectin and MAdCAM-1 (mucosal addressing cell adhesion molecule-1) and integrins (for example, family members, $\alpha 7$ and $\beta 2$ ) that integrate intracellular and extracellular environments, play a prominent role in the immune system [31]. LFA-1 (lymphocyte function antigen), interacts with ICAM-1 (intercellular adhesion molecule) in endothelial cells favoring the entry of eosinophils into the airways, colon and small intestine. There are multiple receptors to recognize lipids such as cysteinyl-leukotrienes, PGD-2 (prostaglandin D-2) and PAF (platelet aggregating factor). The PGD-2 receptor can mediate the transmigration of eosinophils, basophils and Th-2 lymphocytes. Antagonists of this receptor have been studied in persistent moderate asthma in phase II studies [32].

Chemokine receptors have several ligands. For example, CCR1 is linked by MIP (macrophage inflammation protein), CCL-5 (RANTES) and PAF; and CCR3 has 11 ligands that include eotaxins 1, 2 and 3; RANTES (regulated upon activation normal $\mathrm{T}$ cell expressed and secreted), MCP-2, MCP-3, MCP-5 (macrophage chemotactic protein) and PAF. SIGLEC-8 (sialic acid-binding immunoglobulin-like lectin-8) is one of the main receptors that define the unique biology of eosinophil (18). PRR (pattern recognition receptors) are also expressed by eosinophils, particularly TLR (toll-like receptor), NLRs (nucleotidebinding oligomerization domain-like receptors) and RAGE (receptors for advanced glycation end-products) (33). In the TLR group, TLR-7 is the most prominent and regulates adherence, migration, chemotaxis and prolongation of survival. Other receptors expressed by eosinophils are complement receptors, receptors for the Fc fraction (crystallizable fraction) of IgA, IgD, IgM and IgG, which appear to have a role in adhesion, degranulation and synthesis of leukotrienes.

\section{Factors that promote eosinophilia}

IL-5 plays a critical role in all aspects of eosinophilic development. Eotaxin-1 (CCL11), a ligand of CCR3, also promotes eosinophilia, by an independent mechanism of IL-5. The development seems to be a function of IL-5, IL-3 and GM-CSF (granulocyte-macrophage colony series stimulating factor) from bone marrow progenitors. There are several parents such as $\mathrm{CD} 34^{+}, \mathrm{CD} 38^{+}, \mathrm{CD} 45^{+}$, but they can also originate from $\mathrm{CD} 34^{+}$outside of bone marrow, particularly lungs. There is a complex network of transcription factors that promote the development of eosinophil, which includes GATA-1, GATA-2 and CCAAT proteins, but it is not exclusive to promote eosinophilic lineage and can promote other hematopoietic cell lines. GATAs are members of a family of zinc fingers, named for joining the promoter sequence composed of GATA bases [34].

TSLP (thymic stromal lymphopoeitin), IL-25 and IL-33 are alarmins that promote the production of Th-2 cytokines that are IL-5, IL-4, IL-9 and IL-13. They are also produced by ILCs (innate lymphoid cells), such that there are several cellular sources of IL-5 to promote eosinophilia. HMGB1 (high mobility group box 1 protein) is another alarmin that promotes eosinophilia without involving IL-5.

\section{Cellular interactions and significant functions}

The interaction with $\mathrm{T}$ lymphocytes that produce Th-2 cytokines has already been discussed. This association is vital to understand the "program" Th-2 that generates the classic eosinophilic inflammatory profile of bronchial asthma [35]. Although the eosinophil is not a "professional" dendritic cell, it can express on its surface MHC II and CD80 and CD86, process antigens and present them to the T system in an antigen-specific manner. It also has an effect on humoral immunity as "priming" B cells for synthesis of Ig M-specific antigen [36]. The AAM (alternative activated macrophages) recruit eosinophils in tissues and in turn the eosinophils promote the activation and migration of dendritic cells. Eosinophils and mast cells communicate in a symbiotic manner, constituting an "eosinophil-mast cell" axis, which interact to increase their respective capacities. For example, MBP and ECP increase the release of histamine, PGD-2, GM-CSF, TNF- $\alpha$ and IL- 8 from the mast cells; but in turn, the chymase of mast cells increases the survival of eosinophils, recruits them to tissues and facilitates the release of cytokines and chemokines [37].

The precise mechanisms by which eosinophils interact with viruses are not yet well defined. Human respiratory viruses (influenza, parainfluenza, respiratory syncytial, coronavirus and rhinovirus) are among the most common causes of asthma exacerbation. A recent concept is that degranulation of eosinophils constitutes a host antiviral defense mechanism. Eosinophils release immunomodulatory mediators, particularly IL-6, in response to infection with respiratory viral pathogens [38]. The granular EDN protein has anti-HIV inhibitory activity [39]. Eosinophils will prepare the uterus for pregnancy and in the cervix its degranulation is involved in dilation at birth and in postpartum remodeling [19].

\section{Eosinofilos and Pathology}

There is an extensive literature of eosinophilic dysfunction and associated diseases and disorders. Eosinophils as therapeutic objectives have revealed the complex and heterogeneous nature of the pathologies associated with them. Hypereosinophilia is a relatively common disorder ( $4 \%$ in Copenhagen in a large population study in general practice). Defined as values greater than 500 eosinophils $/ \mathrm{mm}^{3}$, it can be divided into two clinical categories; blood hypereosinophilia and tissue hypereosinophilia, each of which may exist alone or may coincide $[40,41]$. Peripheral eosinophilia can be classified as mild (eosinophil count between $\left.500-1,500 / \mathrm{mm}^{3}\right)$, marked $\left(1,500-5,000 / \mathrm{mm}^{3}\right)$ or massive $\left(>5,000 / \mathrm{mm}^{3}\right)$ [42]. Eosinophilia can be primary, secondary, family or idiopathic [43]. Table 1 lists a series of causes of peripheral eosinophilia with respiratory compromise.

\section{Primary causes}

The primary causes of eosinophilia and respiratory symptoms are eosinophilic pneumonia, eosinophilic granulomatosis with polyangiitis (EGPA), also known as Churg-Strauss syndrome and hypereosinophilic syndromes (HES). Acute eosinophilic pneumonia is a febrile, infrequent, severe and progressive condition that develops over a period of days to weeks, with severe hypoxemia, diffuse pulmonary infiltrates and an increase in bronchio-alveolar lavage of eosinophils without evidence of previous infection or atopic disease. Three days of methylprednisolone $60 \mathrm{mg} / 6$ hours I.V, followed by oral prednisone with progressive reduction in the next 12 days is usually sufficient to solve the process [44]. Chronic eosinophilic pneumonia is an idiopathic disease characterized by dyspnea and alveolar infiltrates and usually with a history of asthma [45].

EGPA is a systemic vasculitis of small to medium sized arteries and its most characteristic findings are asthma, peripheral eosinophilia and rhinosinusitis. The six diagnostic criteria of the American College 
Table 1. Differential Diagnosis of Peripheral Eosinophilia and Respiratory Symptoms

\begin{tabular}{|c|c|}
\hline \multicolumn{2}{|l|}{ Primary Causes } \\
\hline \multirow{2}{*}{$\begin{array}{l}\text { Systemic } \\
\text { conditions }\end{array}$} & -Eosinophilic granulomatosis with polyangiitis \\
\hline & $\begin{array}{l}\text {-Hypereosinophilic syndromes: idiopathis, myeloproliferative variant } \\
\text { and lymphocytic variant }\end{array}$ \\
\hline Lung Conditions & -Idiopathic acute or chronic eosinophilic pneumonia \\
\hline \multicolumn{2}{|l|}{ Secondary Causes } \\
\hline \multicolumn{2}{|l|}{ Infections } \\
\hline \multirow[t]{8}{*}{ Parasitic } & -Paragonimiasis \\
\hline & -Tropical pulmonary eosinophilia (lymphatic filariasis) \\
\hline & $\begin{array}{l}\text {-Acute larval migration of ascaris, hookworm or strongyloides } \\
\text { (Loeffler's syndrome) }\end{array}$ \\
\hline & -Schistosomiasis (Katayama syndrome) \\
\hline & -Echinococcal cyst \\
\hline & -Entamoeba histolytica infection (hepatopulmonary amebiasis) \\
\hline & -Disseminated strongyloidiasis \\
\hline & -Toxocariasis (Visceral larva migrana) \\
\hline \multirow[t]{5}{*}{ Fungal } & -Coccidioidomycosis \\
\hline & -Paracoccidioidomycosis \\
\hline & -Histoplasmosis \\
\hline & -Pneumocystis Pneumonia \\
\hline & -Cryptococcosis \\
\hline \multicolumn{2}{|l|}{ Cancer } \\
\hline & -leukaemia and lymphoma \\
\hline & -Lung cancer and others \\
\hline \multicolumn{2}{|l|}{ Drug and toxin } \\
\hline \multicolumn{2}{|c|}{ Connective tissue and autoimmune diseases } \\
\hline & -PAN \\
\hline & -SLE \\
\hline & -RA \\
\hline \multicolumn{2}{|c|}{ Disease involving airways } \\
\hline & -ABPA \\
\hline & -Bronchial asthma Th-2 \\
\hline & -COPD eosinophilic phenotype \\
\hline
\end{tabular}

of Rheumatology are asthma, eosinophilia $>10 \%$ in the differential count of white blood cells, mononeuropathy (including multiplex) or polyneuropathy, non-fixed pulmonary infiltrates on radiography, sinus abnormalities and biopsy with blood vessels with extravascular eosinophils. The presence of 4 or more of these criteria has a sensitivity of $85 \%$ and a specificity of $99.7 \%$ [46]. P-ANCA (antibodies against neutrophil myeloperoxidase in a perinuclear pattern), are helpful in supporting the diagnosis but are positive in less than $50 \%$ of individuals. The diagnosis is confirmed by tissue biopsy [40].

HES, described in 1968 by Hardy and Anderson, is a group of rare disorders characterized by persistent eosinophilia $\left(>1,500 / \mathrm{mm}^{3}\right.$ in two samples with a difference of one month between both), eosinophilic infiltration and dysfunction of several organs, including lung and exclusion of known causes of eosinophilia [47]. They are divided into three categories: Idiopathic, primary or neoplastic (HESN), and secondary or reactive (HESR) [19]. HESN can be subdivided into several phenotypes. M-HES is myeloproliferative and occurs by deletion of chromosome 4 with complex chromosomal abnormality and more frequently with endomyocardial fibrosis. It responds to the imatinib monoclonal antibody (a tyrosine kinase inhibitor), initially used in chronic myelogenous leukemia [48]. There is an overlap between MHES and CEL (chronic eosinophilic leukemia). Another phenotype is L-HES, the lymphocytic variant, which occurs due to aberrant overproduction of IL-5 produced by abnormal polyclonal T cells and high levels of IgE. It particularly occurs with skin manifestations. Familial eosinophilia (an autosomal dominant disorder) is considered a rare variant of HES (49). Eosinophilia can be reactive to systemic mastocytosis and histiocytosis of Langerhans cells [42].

\section{Secondary causes}

Infections: Parasitosis and mycosis are two important considerations in pulmonary infiltrates with eosinophilia. In parasitosis, the laboratory must have a microscopic analysis of feces by concentration for parasites, cysts and eggs. Many serological tests are positive 4-12 weeks postinfection, so the serology can be initially negative, when eosinophilia is detected. Moreover, eosinophilia may be transient associated with the phase of tissue migration, a phase in which parasites or larvae are not detected in feces. When the microorganism reaches the intestine, eosinophilia resolves and parasites appear in feces. It is therefore vital to know the life cycle of parasites to understand the positivity or negativity of the findings and their turn [50].

Acute schistosomiasis (Katayama syndrome) occurs approximately 2-12 weeks after exposure to the organism in fresh water [51]. After the larva penetrates the skin, they travel through the lungs and circulation, suddenly causing fever, cough, skin hives, migratory pulmonary infiltrates on the chest $\mathrm{x}$-ray, and peripheral eosinophilia. Typically the symptoms resolve in 2-10 weeks. Schistosoma species that cause disease in humans are endemic in Asia and the Middle East (Schistosoma japonicum, Schistosoma haematobium, Schistosoma mansoni). Praziquantel $40 \mathrm{mg} / \mathrm{Kg}$ in a single dose or $60 \mathrm{mg} / \mathrm{Kg}$ divided into three doses is the treatment. It should be repeated at 6-8 weeks because the eggs and squistosomules are relatively resistant. A prednisone cycle of $20 \mathrm{mg} /$ day / 5 days reduces the duration of symptoms [52].

Paragonimiasis has an incubation period of 3 days to weeks, after ingesting metacercariae in the intermediate stage of the parasite when eating raw or not well cooked fresh water crab meat. Abdominal pain, diarrhea and rash are followed by chest pain, eosinophilic pleural exudate and cough that become chronic [53]. About 6 months after infection haemoptisis usually appears resembling tuberculosis. CNS infection and migratory subcutaneous nodules may occur. It is more prevalent in East Asia, with an estimated 23 million patients affected worldwide [54]. In Asia $>90 \%$ of cases are produced by Paragonimus westermani. In West Africa, India, Central and South America by Paragonimus sp. 50\% of patients have marked eosinophilia and high IgE. The $\mathrm{x}$-ray may show nodules, infiltrates, pleural effusion or be normal. The sensitivity of sputum microscopy for visualization of eggs is limited even with multiple samples. The serological test has a sensitivity of $96 \%$ and a specificity of more than 95\% [55]. The treatment is Praziquantel $25 \mathrm{mg} / \mathrm{Kg}$ tds/ 2 days. An alternative is Triclabendazole $10 \mathrm{mg} / \mathrm{Kg} /$ day 13 days.

Tropical pulmonary eosinophilia (TPE) is a rare condition that occurs due to an unusual hypersensitivity reaction to filaria antigens of the parasites Wuchereria bancrofti and Brugia malayi [56]. Lymphatics periodically release mature filarial parasites that are trapped in the pulmonary circulation (therefore it is unusual to observe microfilaremia). Degenerated microfilariae release antigens that generate type I, II and IV immune responses and eosinophils attempt to destroy microfilariae, but in this process with the release of granular proteins, they damage the lung by orchestrating the clinical picture [57]. Patients may be asymptomatic or have a cough, wheezing, dyspnea and fever. It is usually confused with asthma. Lymphatic filariasis affects approximately 120 million people worldwide, in 83 countries, including many countries in Southeast Asia [58]. TPE is found in $<1 \%$ of patients with filarial infection. Chest X-ray usually 
shows reticulonodular opacities or miliary infiltrate, but in $20 \%$ of cases they may be normal. Diagnostic criteria include inhabiting or traveling to areas in which the parasite is endemic, peripheral eosinophilia $>3,000$ $/ \mathrm{mm}^{3}$, IgE $>1,000 \mathrm{IU} / \mathrm{ml}$, detection of antifilarial antibodies and rapid defervescence of symptoms with treatment (56). The treatment of choice is diethylcarbamzine $5 \mathrm{mg} / \mathrm{kg}$ /day for 4 weeks. Relapses occur in $20 \%$ of cases and in this scenario monthly courses of the drug are recommended, every 2-3 months for 1-2 years. Without treatment it can evolve into irreversible pulmonary restrictive damage. The WHO strategy tries aims at preventing transmission of microfilaria through mosquito bites.

Hydatid cyst is a pathology produced by Echinococcus granulosus and Echinococcus multilocularis. The most commonly affected organ is the liver but lung cysts can occur in $20 \%$ of cases and also in other organs. It occurs due to the ingestion of eggs that are in canine feces or in contaminated vegetables, and the incubation period goes from months to years. Distribution predominates in the Middle East, Eastern Europe, East Africa and in Central Asia [59]. Many cases are asymptomatic and have no eosinophilia. Cough, dyspnea and pleuritic pain are the most prominent respiratory symptoms. Eosinophilia usually appears when the cysts rupture, whether hepatic or pulmonary. Serology is not always positive and radiological images usually suggest diagnosis. Albendazole (400 mg BID), and praziquantel (20 mg / Kg BID) are recommended 2 weeks before and two weeks after an aspiration or surgery of a cyst. This is due to the risk of anaphylaxis and dissemination of the cyst, so the extraction of these should be performed in centers with experience [60].

Amebiasis can be asymptomatic, or the symptoms appear 2-4 weeks after ingesting mature cysts of amoebas (Entamoeba histolytica) in food or water contaminated with feces or through manual contact. In the small intestine, cysts release trophozoites that travel to the large intestine. The trophozoites are divided by binary fission and in turn, generate more cysts. Both stages pass in the stool. The cysts can survive days to weeks in the external environment by the protection offered by the wall of the cysts that are responsible for the future transmission of the parasite [61]. Symptoms can range from mild abdominal cramps and watery diarrhea to severe colitis with bloody and mucous diarrhea. Toxic megacolon has a high mortality. Globally, 50 million people acquire the infection, with approximately 100,000 deaths annually. While it is true the most frequent route of dissemination is oral-fecal, cases of sexual transmission have been reported (anal or oral sex) [62]. There is no vaccination or prophylactic medication. Prevention requires adequate health care, with strict excreta deposition and water purification. $4 \%$ of patients develop amoebic liver abscess with fever and pain in the upper right abdominal quadrant and may open into pericardium or pleura with associated effusions in these serous. From gastrointestinal tract amebiasis can affect any organ. Rectal swab and microscopic stool examination are positive in only $30 \%$ of cases, ELISA and PCR can be performed to detect antigens, although the most promising method is the loop-mediated isothermal amplification assay. The treatment is based on hydration, metronidazole or tinidazole [63].

Acute larval migration (Loeffler syndrome) is a self-limited pathology, caused by transpulmonary larval migration that occurs early in the normal life cycle of several helminths, including Ascaris lumbricoides, hookworm (Ancylostoma duodenale and Necator americanus) and Strongyloides stercolaris. The incubation period is 1-2 weeks, depending on the species, with fever, cough, wheezing, rash and rarely hemoptysis [64]. Marked eosinophilia may appear and migratory infiltrates are seen on the chest radiograph. The disease lasts days to weeks and then the symptoms decrease. Serological positive tests for antibodies against strongyloides may be found, but may constitute evidence of previous infection. Negative stool test for eggs and parasites does not rule out infection. Strongyolides can persist for decades. It is a common infection with an estimated 100 million people affected in the world [63]. In travelers, migrants or residents of countries with a high prevalence of parasites, empirical treatment with albendazole (400 $\mathrm{mg} \mathrm{BID} \mathrm{oral/day/} 3$ days) is indicated [50]. Larva currens is a frequent manifestation of strongyloides, in which the larvae penetrate the skin of humans who walk barefoot through soil or sand contaminated, and course basically with non-specific gastrointestinal manifestations.

Larva visceral migrans (acute toxocariasis) occurs when eggs of Toxocara canis or Toxocara catis are ingested, which are found in soils contaminated with dog or cat feces or by ingesting raw meat, particularly liver [65]. The eggs generate larvae that penetrate the intestinal mucosa, enter the portal circulation and then into the systemic circulation. Larva migrans ocular is a distinct syndrome and does not present with eosinophilia. The incubation period is uncertain and the distribution is worldwide including temperate areas. It can be asymptomatic, particularly children under 5 years of age or with fever and eosinophilia, wheezing and cough. Abdominal pain, hepato-splenomegaly and rash can occur. It can cause eosinophilic meningoencephalitis [50]. The research is done by serology, many cases are mild and self-limited and the treatment is based on albendazole ( $400 \mathrm{mg}$ BID oral/day/5 days). Steroids and antihistamines may be necessary in cases of hypersensitivity [66]. A high load of toxocara or strongyloides parasites can produce a hyperinfection syndrome that results from cycles of autoinfection and unchecked replication in individuals with defective granulocytic function associated with malignancy, chemotherapy, steroid use or HIV-1 infection. With strongyloides, the paralytic ileus and gram negative sepsis follow bacterial translocation through the intestinal wall and have high mortality. Pulmonary involvement occurs with abundant amount of larvae in sputum as well as in feces. Mortality is high. Stool by concentration and serology have a high sensitivity diagnostic. Ivermectin $200 \mu \mathrm{g} / \mathrm{Kg}$ a single daily dose (including I.V) for a prolonged course is preferred to albendazole. Hyperinfection should be treated with broad-spectrum antibiotics. Patients from tropical areas, travelers or migrants from these areas should be screened by strongyloides (even in the absence of peripheral eosinophilia) before starting immunosuppressive therapy or steroids [67].

There are other parasitosis that occur with eosinophilia but mainly have gastrointestinal symptoms, for example, the tapeworm, due to eating raw or undercooked meat. Taenia saginata predominates in Africa (beef) and Taenia solium in America and Asia (pork). Segments of the parasite can pass through feces and are sometimes actively expelled through the rectum [68]. Hymenolepis nana had a dwarf tapeworm associated with poor hygiene, especially in children and mainly in America, Africa and India [69]. Trichuris trichiura has a wide worldwide distribution. It's acquired by the fecal-oral route and mainly affects children, with anemia, dysentery and rectal prolapse. The pin worm Enterobius vermicularis has the same distribution, route and age group as trichuris and it has intense anal itching. Microscopic analysis for eggs on an adhesive tape placed in the perianal region at night often resolves the diagnosis [70]. Trichinellosis produced by Trichinella $s p$ occurs by eating undercooked or raw pork. Widely distributed worldwide, the ingested larvae mature in the enteral phase, producing parenteral migration from the intestine to the muscle where the larva is encysted. The enteral phase produces gastrointestinal symptoms and the muscular phase produces myalgia, muscle weakness, dysphagia in respiratory failure [71]. Virtually all of these entities are treated with albendazole or praziquantel. Angiostrongylus costaricensis was described 
in Costa Rica by Morera and Céspedes, with an unknown incubation period and distributed mainly in Central America and the Caribbean. It is acquired by the ingestion of snails or vegetables contaminated with snail droplets with severe abdominal pain, diarrhea or constipation and eosinophilia. It is usually a finding of laparotomy. In endemic areas there is serology for diagnosis. Treatment: supportive [72].

Mycoses that occur with respiratory symptoms and eosinophilia are listed in Table 1. Coccidioidomycosis (Coccidioides immitis and Coccidioides posadasii) and paracoccidioidomycosis (Paracoccidioides braziliensis) have many features in common. Coccidioidomycosis has an incubation period of 7-21 days (although reactivation by immunosuppression can occur many years later) and paracoccidioidomycosis from 1 month to many years. The first has a distribution in all the Americas while the second basically in Central and South America [73]. Both are acquired by spores (arthroconidia) of the fungus by air. Coccidioidomycosis presents fever, cough, pleuritic pain, headache and rash while paracoccidioidomycosis is more insidious, with cough, fever, night sweats, weight loss, malaise, and oral, nasal and skin ulcers. Disseminated chronic meningitis can occur in an immunocompromised host. Radiography shows consolidation, cavitation and pleural effusion (coccidioidomycosis) and hilar adenopathy (paracoccidioidomycosis). Eosinophilia is common in both. The diagnosis requires serology or microscopy and culture of respiratory samples. Spontaneous resolution is frequent in immunocompetent host. Oral Itraconazole (200-400 mg once daily) or fluconazole (400-800 mg once daily) for 3-6 months is the treatment of choice. In severe cases a 2 week cycle of amphotericin B (3 mg / kg per intravenous day) is necessary [50].

Pneumocystis jiroveci pneumonia (PCP) is the fungal infection that most affects human immunocompromised hosts. Those are cancer patients, with HIV, transplant recipients, and patients with medication and immunosuppressive therapies. The fungus adheres to the type I alveolar cell where the transition from the small trophic form to the large cystic form occurs. What causes diffuse alveolar damage is not the fungus itself, but the host's inflammatory response [77]. Clinically the picture can vary from a mild and indolent picture of cough, low grade fever and dyspnea to respiratory failure and distress. High levels of LDH not being specific to PCP, is helpful in patients with HIV, but in nonHIV immunocompromised hosts, it has no value. The chest $\mathrm{x}$-ray shows perhilar and diffuse interstitial infiltrates that become homogeneous as the disease progresses. In normal chest radiology, the chest CT scan may show ground glass or cysts with high sensitivity for PCP [78]. As Pneumocystis cannot be cultured, the definitive diagnosis requires PCR, specific stains or with fluorescent antibodies. The treatment of choice is Trimethoprim-Sulfametoxazole (TMP-SMX). TMP 15-20 mg / Kg / day and SMX, 75-100 mg / Kg / day, for 21 days, orally in three doses, or TMP-SMX DS 2 tablets 3 times a day for 21 days. Alternative drugs in different regimens for patients allergic to sulfa include Atavaquone, Dapsone, Primaquine, Clindamycin, and Pentamidine. In a moderately to severely infected HIV patient, a prednisone regimen (40 mg BID / 5 days, $40 \mathrm{mg} /$ day / 5 days and then $20 \mathrm{mg} /$ day / 11 days) improves clinical outcomes and reduces mortality. Prophylaxis with TMP-SMX is recommended in certain populations of HIV-infected patients such as with a CD4 $+<200$ cell / $\mu \mathrm{l}$ count, or CD $4+<14 \%$ in the presence of oropharyngeal candidiasis, or CD4+200-250/ $\mu$ lif it cannot be start antiretroviral therapy (ART) or you cannot count CD4+ every 3 months. Originally PCP was considered a disease associated with the definition of AIDS, but due to prophylactic therapy and ART therapy, the incidence of PCP in patients with HIV has decreased dramatically [79].
Cryptococcosis is an opportunistic mycosis produced by encapsulated yeasts, of universal distribution, that occurs through the inhalation of balstoconidia from the fungus Cryptococcus neoformans or C. gattii. C neoformans is found in soil contaminated with bird droppings, particularly pigeons, and protected from direct sunlight. This dried medium, alkaline and rich in nitrogen substances constitutes an ideal ecological niche for the development of the fungus. C. gattii is mainly associated with trees, especially eucalyptus. The risk factors are immunosuppression states, similar to those of Pneumocystis jiroveci [80]. In the immunocompetent host the respiratory infectious process is mild, asymptomatic and of rapid resolution. The incubation period is not well established because clinical manifestations depend on the host's immune status. If respiratory symptoms appear, the symptoms are cough, fever, chest pain, weight loss and poor general being. Pneumonic consolidation, pleural effusion, miliary dissemination and regional adenopathies may occur. The microorganism has tropism by central nervous system and particularly in patients with HIV disease, generates cryptococcal meningitis, which is the most frequent and severe form of presentation (mortality between 15-60\%) and is responsible for at least 100,000 deaths / year in HIV patients [81]. The diagnosis can be made by direct examination (exclusion technique with Chinese ink) or culture, for example of CSF or sputum; with specific biopsy colorations (Meyer mucarmine, Alcian blue and Masson-Fontana); and with immunological tests that determine cryptococcal capsular antigens (latex agglutination sensitized with antibodies against the antigen, ELISA or lateral flow immunochromatography) in CSF or blood. Primary prophylaxis in patients with HIV $(C D 4+<100 / \mu l)$ is given with fluconazole $200 \mathrm{mg}$ / day VO. In disseminated or CNS cryptococcosis, amphotericin IV (0.7 mg / kg / day), plus 5 fluocytosine (100 mg / kg / day) divided into 4 doses / 2 weeks, is the treatment of choice. If 5 flucytosine is not available, it can be substituted with fluconazole (800 $\mathrm{mg} /$ day) plus amphotericin for 2 weeks. After this induction phase, an 8-week consolidation phase with fluconazole ( $800 \mathrm{mg} /$ day V.O.) is implemented. The maintenance phase or secondary prophylaxis is done with fluconazole 200-400 mg / day V.O. ART should be started 2-10 weeks after the start of antifungal therapy. If inflammatory immune syndrome is present, steroids should be given I.V. or oral for 2-6 weeks. Mild to moderate forms of pulmonary cryptococcosis are treated only with fluconazole for 6-12 months ( $400 \mathrm{mg} /$ day V.O.) and severe forms such as CNS cryptococcosis [82].

\section{Cancer}

There are myeloid and lymphoid neoplasms associated with eosinophilia. When a pathologist receives a sample of peripheral blood or bone marrow, the focus of research should be these two neoplasms since there is little that can offer in a non-neoplastic eosinophilia. The myeloid neoplasms associated with eosinophilia are chronic myelogenous leukemia, chronic eosinophilic leukemia and acute myeloid leukemia. Eosinophils are produced by abnormal myeloid progenitor cells. In contrast, in lymphoid neoplasms associated with eosinophilia, it's produced by cytokines. T-cell neoplasms are the most common associated with eosinophilia (cutaneous T-cell lymphoma, adult T-cell leukemia / lymphoma and angioimmunoblastic T-cell lymphoma). The B-cell neoplasms most commonly associated with eosinophilia are: Hodgkin lymphoma, and B-lymphoblastic lymphoma / leukemia. Recent publications have excellent reviews of the subject and of diagnostic work at the molecular level [42]. Lung cancer and others have been associated with eosinophilia and some authors consider it a paraneoplastic syndrome. 


\section{Drugs and toxins}

Antibiotics such as $\beta$-lactams, nitrofurantoin, minocycline and daptomycin may be associated with eosinophilia, as well as non-steroidal anti-inflammatory drugs, mesalamine, sulfasalazine and others. Also DRESS (drug reaction with eosinophilia and systemic symptoms), cocaine and heroin [83]. With the recent report of 53 cases of lung disease associated with the use of E-cigarette in Illinois and Wisconsin, none of the patients in which eosinophils were reported had values greater than $2 \%$, and the prevalence was neutrophilia [84]. In 17 lung biopsies, in a preliminary report, of patients with a history of vaping ( $71 \%$ was associated with marijuana or cannabis oil), a predominance of eosinophils was not demonstrated in histological samples. Since this pathology is of recent description, an attentive attitude must be maintained with respect to its pathogenesis and surveillance on the cellular profile of the lesions in more powerful cases [85].

\section{Connective tissue and autoimmune diseases}

Polyarteritis nodosa (PAN) is a vasculitis that results from inflammation and injury to vessels of medium and small caliber leading to ischemia in a variety of organs and tissues, although the kidneys are not usually compromised. The low renal compromise and negative ANCA differentiate PAN from other systemic necrotizing vasculitis. Eosinophilia is occasionally seen but, when present, EGPA should be considered [86]. There are no studies on the incidence and severity of eosinophilia in Systemic Lupus Erythematosus, but eosinophils are not part of the diagnostic criteria for the condition. 3\% of patients with Rheumatoid Arthritis have eosinophilia, which is usually minimal and transient, but seems to predict a poor response to disease-modifying anti-rheumatic drug [87]. Eosinophilic fascitiis (Shulman disease) is a rare scleroderma-like syndrome, of unknown cause, which can be immunologically mediated with painful edema and progressive induration and thickening of skin / soft tissues of limbs and trunk. Course with eosinophilia, hypergammaglobulinemia and increased erythrosedimentation rate [88]. Other rare and poorly characterized myopathies are toxic oil syndrome, myalgia-eosinophilia syndrome and eosinophilic myositis [18].

\section{Diseases involving airways}

Peripheral eosinophilia is a central change in allergic bronchopulmonary aspergillosis, which is a reaction of hypersensitivity to colonization of the airway by the ubiquitous mold aspergillus [45]. Affected patients typically have cough and exacerbations of asthma, and recurrent pulmonary infiltrates which can progress to bronchiectasis and pulmonary fibrosis [89]. Diagnostic criteria include a history of asthma or cystic fibrosis, elevated aspergillus-specific IgE and IgG for aspergillus, increased serum IgE ( $>1000 \mathrm{ng} / \mathrm{ml}$ or $>410 \mathrm{iu} / \mathrm{ml}$ ), whealand-flare skin reaction for aspergillus antigen and high eosinophilia [88]. Exacerbations improve with the administration of prednisone.

An extensive review of asthma and chronic obstructive pulmonary disease, with its differences, similarities and controversies has been published recently in this journal, so in this monograph we will only discuss relevant aspects of both, insofar as they can be accompanied by peripheral eosinophilia [90]. Endotype is a subtype of condition defined by a different pathological mechanism. In asthma we have two endotypes; asthma Th-2 and asthma non-Th2 [91]. In the Th-2 endotype, the phenotype is basically eosinophilic and within it there is a subgroup with severe eosinophilic asthma refractory to conventional treatment [92]. The non-Th-2 endotype is also known as non-eosinophilic asthma (NEA). Chung classifies them as asthma "Th-2 high inflammation" and asthma "Th-2 low inflammation" (NEA) [93]. 50\% of asthmatics will have the eosinophilic phenotype and the other $50 \%$ will have the NEA. There is not always a clear correlation between clinical phenotypes and molecular endotypes. In the Th-2 endotype, immunity is orchestrated by CD4+ T helper- 2 that secrete interleukins IL-4, IL-5, IL-9, and IL-13, which lead to airway infiltration with eosinophils, mast cells, and B cells (which produce IgE in response to allergens) [94]. The point is that these patients have peripheral eosinophilia and airway infiltration with eosinophils. Patients with NEA do not have significant eosinophilia and in this group there are several phenotypes such as neutrophilic, paucigranulocytic and mixed pattern (eosinophils and neutrophils). These patients have various risk factors such as smoking, pollution, occupational exposure, recurrent infections and obesity. It is difficult to separate NEA from COPD particularly in people of older age because they easily overlap, have similar spirometric patterns and similar molecular mechanisms that generate them. In both, the T-cell program is directed towards Th- 1 , Th-17, which attract neutrophils and macrophages but not eosinophils [95] (Figure 2). This type of asthma is more severe and responds less (like the mixed pattern) to glucocorticosteroids.

The GINA 2019 guidelines clearly define that the first-choice relief treatment is the use of low doses of IGCs + formoterol PRN (for necessary reason) in the 5 steps and that the use of SABA PRN is an alternative. But they also establish that in step 1 (mild intermittent asthma) the choice of controller treatment is the same association of low doses of IGCs + formoterol PRN since this alternative is superior to SABA PRN in this subgroup of asthmatics with respect to the prevention of exacerbations [96]. There is no doubt that the risk of asthmatic exacerbations decreases if daily IGCs are used; but the problem is the reluctance to use them since the symptoms, in mild intermittent asthma, are mild and infrequent and the patient ends up using only the rescue SABA (PRN) in the real world, and does not use the IGC on a regular basis. In step 2 GINA recommends the use of IGCs in low doses, daily and on a regular basis, but leaves the use of IGCs + formoterol PRN as an alternative, because in this group of patients with persistent mild asthma, adherence to the regular scheme is also very poor, and asthma

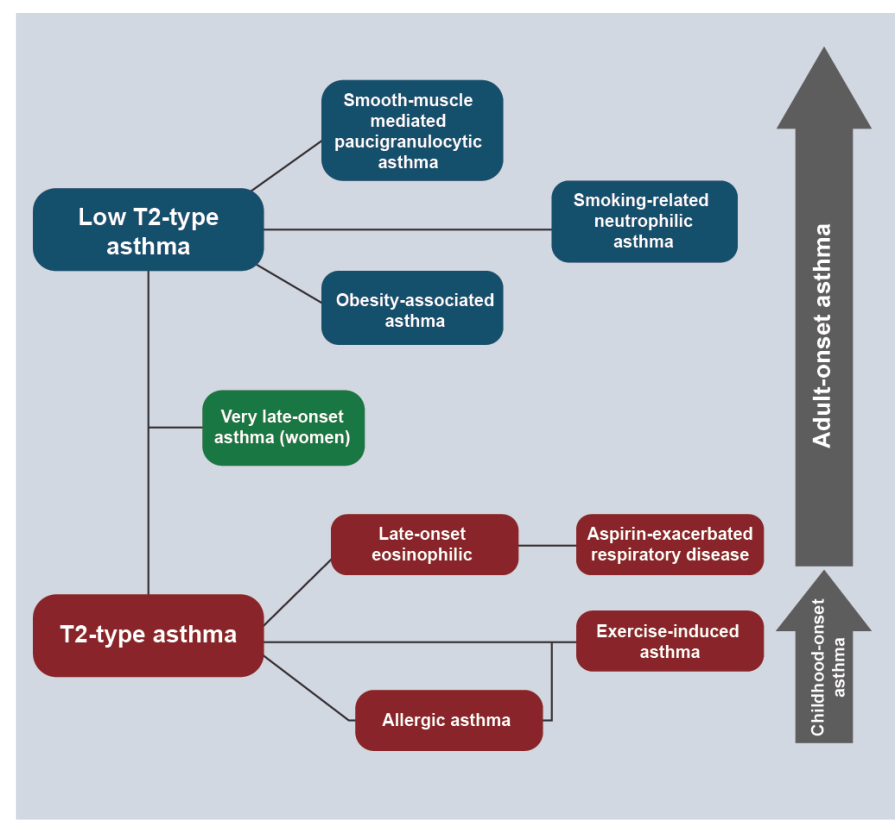

Figure 2. Emerging Asthma Phenotypes

See molecular endotypes on the left and clinical phenotypes on the right. 
control worldwide is sub-optimal [97]. In the works SYGMA 1 and SYGMA2 it was demonstrated that the use of budesonide + formoterol PRN was as effective as the use of regular maintenance of budesonide to prevent exacerbations in persistent mild asthma (98.99). The Novel START, an extension of the works previously cited, also showed that the budesonide + formoterol PRN association is superior to the use of SABA in preventing exacerbations in adults with mild asthma [100]. However, symptom control is superior with maintenance budesonide and SABA PRN, but again, the strictly controlled study strategies in this group of asthmatics are not applicable to them in the real world.

The detail again is the clinical phenotype. If it is eosinophilic, the response to IGCs is adequate, but that occurs in mild asthma if the phenotype is non-eosinophilic? It is known that this phenotype has much lower response to IGCs, therefore giving them IGCs + LABA either maintenance or PRN could lead to covert monotherapy and increased exacerbations in the real world. The SIENA study suggests that maintenance therapy for this subgroup of asthmatics is yet to be determined (101). In $5 \%$ of patients with moderate to severe asthma, maintenance IGCs are given in low, medium or high doses plus LABA, adding leukotriene receptors inhibitors or tiotropium receptor inhibitors and in $1 \%$ biological in step 5 or oral steroids. Asthmatic patients with eosinophilia $>400$ cells / $\mu$ l experience more exacerbations and have poor asthma control (Figure 3) [102].

Blocking type 2 immunity is a strategy for the treatment of refractory eosinophilic asthma. Blocking IgE with omalizumab, in patients with severe allergic asthma and with high levels of IgE is accepted, as well as blocking IL-5 or its receptor (IL-5R $\alpha$ ), are part of the recommendations of GINA 2019. Subcutaneous mepolizumab and reslizumab intravenous are monoclonal antibodies that block IL-5 and subcutaneous benralizumab, IL-5Ra. Dupilumab (which blocks the alpha subunit of the IL-4Ra receptor) is effective in patients with moderate to severe asthma with eosinophilia since it blocks the regulation of IgE synthesis (Figure 4) [103-106]. Figure 5 shows the indications of GINA for the use of biologicals in asthma.

Chronic rhinitis has a prevalence of $30 \%$ in the adult population worldwide. It may or may not be associated with chronic sinusitis. Most patients with chronic rhinosinusitis and nasal polyposis have a Th-2 type of inflammation, with eosinophils and Th-2 cytokines. Hence, the frequent association with allergic asthma [107].

Many patients with COPD have minimal disease that only requires smoking cessation, anti-influenza and pneumococcal immunization and SABA and/or SAMA rescue. Only the minority require more treatment. In these patients, the most effective treatment is not IGCs, but long-

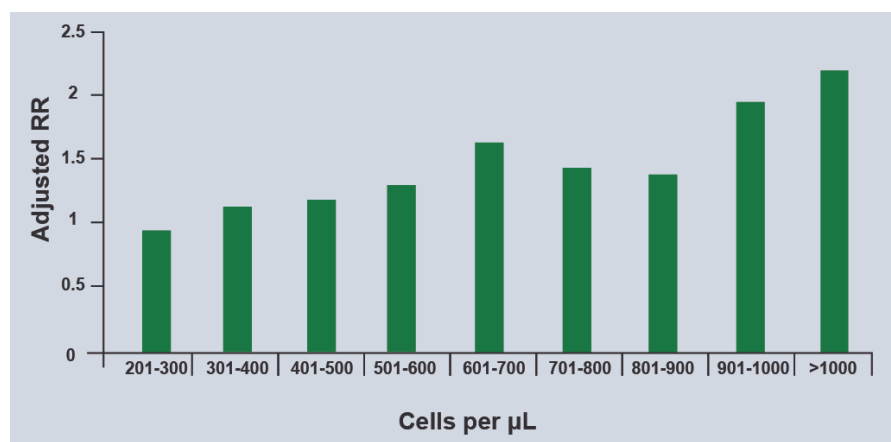

Figure 3. Relationship of Blood Eosinophils with Severe Asthma Exacerbations Note that the higher eosinophils count in peripheral blood, the greater the risk of exacerbations.

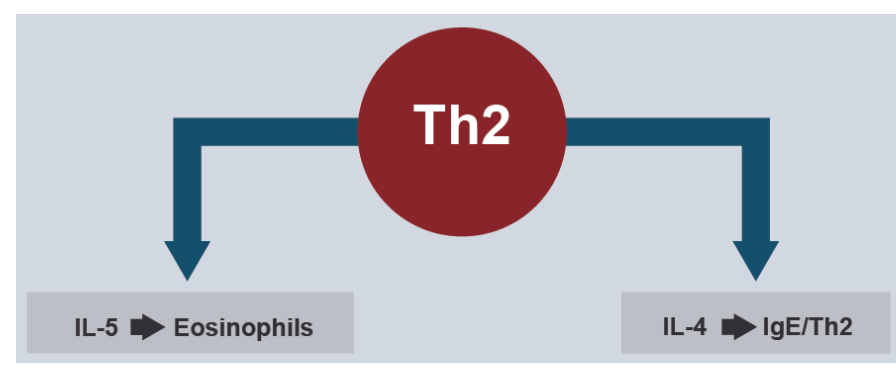

Figure 4. Targets for Biological Treatment of T2-Type Asthma IL-5 promotes differentiation of hematopoietic precursor from eosinophils and IL-4 regulates the synthesis of IgE.

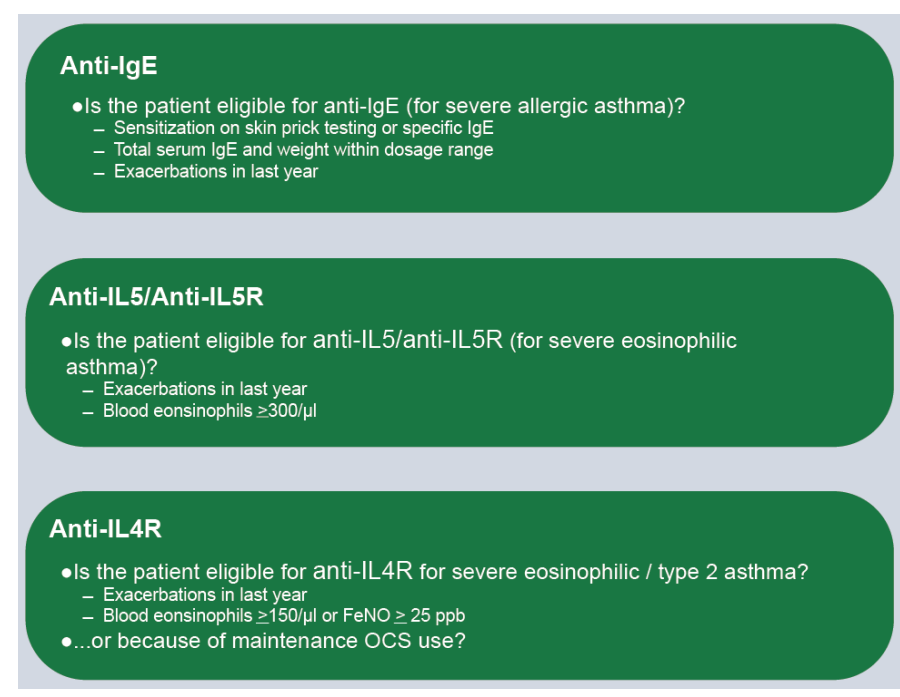

Figure 5. The indications for each group of monoclonal antibodies are listed

acting bronchodilators (SAMA and LAMA) that reduce hyperinflation, symptoms and acute exacerbations (108). Inhaled steroids are added in case of frequent and severe exacerbations or in the presence of ACO (asthma and COPD overlap) [109]. The majority of these patients have the immune program 1 and 3 (Th-1 and Th-17 with infiltration with macrophages and neutrophils predominantly), however up to $40 \%$ of COPD in some series may have a predominance of eosinophils (Th-2) which predicts a better response to steroids but also a greater likelihood of exacerbations [110,111]. Peripheral eosinophils of $>2 \%(150-200$ eosinophils / $\mu \mathrm{l}$ and / or sputum eosinophilia between $2-4 \%$ seem to predict this response [112-114]. Anti-IL-5 antibodies have been used in COPD (benralizumab and mepolizumab) in studies that have shown a reduction in exacerbations, but not in symptoms or quality of life [115-117]. Anti-IL-4 and anti-IL-13 antibodies have not been studied in COPD or ACO. Neutrophilic has also been the subject of biologicals in COPD but has not shown clinical benefits [90].

\section{Other significant associations}

Eosinophilia in CSF is always abnormal and suggests parasitosis, fungi, viruses, neoplasms and other rare CNS conditions. The point is that its presence in CSF should always activate a diagnostic work [3]. At the gastrointestinal level, eosinophilia can be associated with eosinophilic gastroenteritis, eosinophilic colitis and eosinophilic esophagitis. The latter condition is associated with allergic rhinitis, asthma, food allergy and atopy family history (20-80\%) [118]. Findings of sensation of retrosternal burn, dysphagia and esophageal stenosis 
frequently confuse it with gastroesophageal reflux, so atopic diathesis and eosinophilia should suggest the diagnosis. Atopy seems to be an important factor but not mediated by $\operatorname{IgE}$ but by $\operatorname{IgG}_{4}$ which, as we know, can behave like a reagin. Th- 2 cytokines promote eosinophilic infiltration and activation of TGF- $\beta$ (transforming growth factor beta), remodeling and esophageal stenosis. Diet, esophageal dilations and drugs are the therapeutic options. Budesonide (drinkable ampoules) 1 $\mathrm{mg}$ / day swallowed in children, and 2-4 mg / day in adults, after meals, is an alternative. It works in Europe in the design of budesonide tablets. As in asthma, mepolizumab reduces inflammation and remodeling, but has little impact on symptoms [119]. Sarcoidosis is a granulomatous disease of a multi-systemic nature, of unknown etiology, characterized by an infiltration of Thelper lymphocytes in the affected sites and which may occur with eosinophilia, as well as some patients with idiopathic pulmonary fibrosis [120]. In the critical care scenario, the most frequent cause of eosinophilia is the adrenal crisis, which in addition to the clinical data, is accompanied by hyperkalemia, hypoglycemia, neutrophilia and lymphocytosis [121].

\section{Conclusions}

Eosinophils should not be conceptualized as cells that simply mark allergy or parasitosis.

Its potent protein arsenal, its receptor network, active interaction with other cells and with chemical mediators profile, define them as cells of cardinal importance in the immunoregulation circuits of innate immunity and acquired immunity.

Their regulated participation is beneficial in normal homeostasis, but their presence and dysregulated activity leads to a series of pathologies in which they are primary or secondary actors producing immune, inflammatory and tissue damage.

While it is true that we now know more and better their role in health and disease, the growing number of idiopathic pathologies associated with their presence suggests that there is still much to study, learn, and define about these intriguing cells. The design of monoclonal antibodies that block the interleukins that regulate their reproduction, traffic and activity are a good example of how knowledge of their function, allows to design new molecules that impact the pathologies in which they are involved.

It is likely that clarifying the relationship between eosinophilic degranulation and tissue remodeling allows the design of future therapeutic strategies for diseases and disorders characterized by eosinophilic dysregulation.

\section{Funding}

No.

\section{Conflict of interest}

No.

\section{Author contribution}

This work was only carried out by the author. Author AA contributed in the planning, data collection, data analysis, writing and critical review. AA read and approved the final manuscript.

\section{Reference}

1. Jones TW (1846) The blood corpuscle considered in its different phases of development in the animal series: I. Vertebrata. Philos Trans R Soc Lond 136: 632.
2. Ehrlich P (1879) Über die spezifischen Granulatione des Blutes. Arch Physiol 3:571.

3. Boza CR (1985) Significado de la eosinofilia en el líquido cefalorraquídeo. Rev Costarric Cienc Med 6: 67-77.

4. Guido I, Alvarado A (1991) La reacción tardía en asma bronquial. AMC 34:94-111.

5. Gleich GJ (1988) Current understanding of eosinophil function. Hosp Pract (Off Ed) 23: 137-147, 151-4, 159-60. [Crossref]

6. Weller PF (1991) The immunobiology of eosinophils. N Engl J Med 324: 1110-1118 [Crossref]

7. Hansel TT, De Vries IJ, Iff T, Rhis S, Wandzilak M, et al (1991). An improved immunomagnetic procedure for the isolation of high purified human blood eosinophils. J Immunol Methods 145: 105-110.

8. Hansel TT, De Vries IJ, Carballido JM, Braun RK, Carballido-Perrig N, et al (1992) Induction and function of eosinophil intercellular adhesion molecule-1 and HLA-DR. $J$ Immunol Methods 149: 2130-2136.

9. Chu VT, Fröhlich A, Steinhauser G, Scheel T, Roch T, et al. (2011) Eosinophils are required for the maintenance of plasma cells in the bone marrow. Nat Immunol 12: 151-159. [Crossref]

10. Brink R (2011) New friends for bone marrow plasma cells. Nat Immunol 12: 115-117. [Crossref]

11. Wu D, Molofsky AB, Locksley RM (2011). Eosinophils sustain adipose alternatively activated macrophage associated with glucose homeostasis. Science 332: 243-247.

12. Samoszuk M1 (1997) Eosinophils and human cancer. Histol Histopathol 12: 807-812. [Crossref]

13. Meleg-Smith S, Gauthier PM (2005) Abundance of interstitial eosinophils in renal allografts is associated with vascular rejection. Transplantio 79: 444-450.

14. Trull AK, Akhlaghi F, Charman SC, Edenberg S, Majid O, et al (2004) Immunosuppression, eotaxin and the diagnostic changes in eosinophils that precede early acute heart allograft rejection. Transpl Immunol 12: 159-166.

15. Weinstock JV (2015) Do We Need Worms to Promote Immune Health? Clin Rev Allergy Immunol 49: 227-231. [Crossref]

16. Horsinger RW (1976) The eosinophil in allergy and asthma. In: Weiss and Segal (Eds) Bronchial Asthma. Mechanisms and therapeutics (1st Edn) Little, Brown and Company (Inc). USA pp: 649-662.

17. Gebreselassie NG, Moorhead AR, Favre V, Gagliardo LF, Lee NA, et al (2012). Eosinophils preserve parasitic nematode larvae by regulating local immunity. $J$ Immunol 188: 427-425.

18. Rosenberg HF, Dyer KD, Foster PS (2013) Eosinophils: changing perspectives in health and disease. Nat Rev Immunol 13: 9-22. [Crossref]

19. Liao W, Long H, Chang CC, Lu Q (2016) The Eosinophil in Health and Disease: from Bench to Bedside and Back. Clin Rev Allergy Immunol 50: 125-139. [Crossref]

20. Young JD, Peterson CG, Venge P, Cohn ZA (1986). Mechanism of membrane damage mediated by human eosinophil cation protein. Nature 321: 613-616.

21. MacPherson JC, Coimhair SA, Erzurum SC, Klein DF, Lipscomb MF, et al (2001) Eosinophils are a major source of nitric oxide-derived oxidants in severe asthma: characterization of pathways available to eosinophils for generating reactive nitrogen species. J Immunol 166: 5763-5772.

22. Gleich GJ, Loegering DA, Bell MP, Checkel JL, Ackerman SJ, et al (1986). Biochemical and functional similarities between human eosinophilic-derived neurotoxin and eosinophil cationic protein: homology with ribonucleasa. Proc Natl Acad Sci USA 83: 3146-3150.

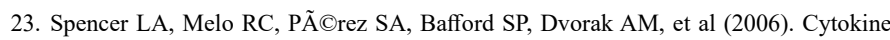
receptor-mediated trafficking of preformed IL-4 in eosinophils identifies an innate immune mechanism of cytokine secretion. Proc Natl Acad Sci USA 103: 3333-3338.

24. Lacy P, Stow JL (2011). Cytokine release from innate immune cells: association with diverse membrane trafficking pathways. Blood 118: 9-15.

25. Charcot JM, Robin C (1853) Observation de leucocythémie. Cir SG (Eds) Soc Biol 5: 44.

26. Su J (2018) A breve history of Charcot-Leyden protein/galectin-10 research. Molecules 23: E2931-E2931.

27. Cummings RD, Liu FT, Vasta GR (2017). Galectins. In: Varki A, Cummings RD, Esko JD (Eds) Esentials of glycobiology. (3rd Edn) Cold Spring Harborg, Cold spring Harbor laboratory Press, NY. 
28. Person EK, Verstraete K, Heyndrickx I, Gevaert E, Aegaerter H, et al (2019). Protein crystallization promotes type 2 immunity and is reversible by antibody treatment. Science 24: 364-364.

29. Dunican EM, Elicker BM, Gierada DS, Nagle SK, Schiebler ML, et al. (2018) Mucus plugs in patients with asthma linked to eosinophilia and airflow obstruction. $J$ Clin Invest 128: 997-1009. [Crossref]

30. Fahy JV, Locksley RM (2019) Making Asthma Crystal Clear. N Engl J Med 381: 882884. [Crossref]

31. Forbes E, Hullett M, Ahrens R, Wagner N, Smart V, et al (2006). ICAM-1-dependent pathways regulate colonic eosinophilic inflammation. J Leucoc Biol 80: 330-341.

32. Barnes N, Pavord I, Chuchalin A, Bell J, Hunter M, et al. (2012). A randomized, doubleblind, placebo-controlled study of the CRTH2 antagonist OC000459 in moderate persistent asthma. Clin Exp Allergy 42: 38-42.

33. Kvarnhammar AM, Cardell LO (2012) Pattern-recognition receptors in human eosinophils. Immunology 136: 11-20.

34. Bedi R, Du J, Sharma K, Gomes I, Ackerman SJ, et al (2009) Human C/EPB-epsilon activator and repressor isoforms differentially reprogram myeloid lineage commitment and differentiation. Blood 113: 317-327.

35. Alvarado A (2019) Differences, similarities and controversies between bronchial asthma and chronic obstructive pulmonary disease. Clin Res Trials 5: 1-12.

36. Wang HB, Ghiran I, Matthaei K, Weller PF (2007) Airway eosinophils: allergic inflammation recruited professional antigen-presenting cells. J Immunol 179: 7585-7592.

37. Wong CK, Ng SS, Lun SW, Cao J, Lam CW (2009) Signalling mechanisms regulating the activation of human eosinophils by mast-cell-derived chymase: implications for mast cell-eosinophil interaction in allergic inflammation. Immunol 126: 579-587.

38. Dyer KD, Perocopo CM, Fischer ER, Gabryszewski SJ, Rosenberg HF (2009) Pneumoviruses infect eosinophils and elicit MyD-dependent- release of chemoacttractant cytokines and interleukin-6. Blood 114: 2649-2656.

39. Rugeles MT, Trubey CM, Bedoya VI, Pinto LA, Oppenheim JJ, et al (2003) Ribonuclease is partly responsible for the HIV-1 inhibitors effect activated by HLA alloantigen recognition. AIDS 17: 481-486.

40. Butt NM, Lambert J, Ali S, Beer PA, Cross NC, et al. (2017) Guideline for the investigation and management of eosinophilia. Br J Haematol 176: 553-572. [Crossref]

41. Gotlib J (2014) World Health Organization-defined eosinophilic disorders: 2014 update on diagnosis, risk stratification, and management. Am J Hematol 89: 325-337.

42. Boyer DF (2016) Blood and Bone Marrow Evaluation for Eosinophilia. Arch Pathol Lab Med 140: 1060-1067. [Crossref]

43. Antonucci R, Vacca N, Boz G, Lucci C, Mannazzu R, et al (2018). Parasitic hypereosinophilia in childhood: a diagnostic challence. Mediterr J Hematol Infect Dis 10: e2018034

44. Rhee CK, Min KH, Yim NY, Lee SE, Chung MP, et al (2013). Clinical characteristics and corticosteroid treatment of acute eosinophilic pneumonia. Eur Respir J 41: 402409 .

45. Cottin V, Cordier JF (2012) Eosinophilic lung diseases. Immunol Allergy Clin North Am 32: 557-586. [Crossref]

46. Masi AT, Hunder GG, Lie JT, Michel BA, Bloch DA, et al (1990). The American College of Rheumatology 1990 criteria for the classification of Churg-Strauss syndrome (allergic granulomatosis and angiitis. Arthritis Rheum 33: 109-1100.

47. Hardy WR, Anderson RE (1968) The hypereosinophilic syndrome. Ann Inter Med 68:1220-1229.

48. Kahn JE, Blétry O, Guillevin L (2008) Hypereosinophilic syndromes. Best Pract Res Clin Rheumatol 22: 863-882. [Crossref]

49. Rouffose F, Cogan E, Goldman M (2007). Lymphocytic variant hypereosinophilic syndromes. Immunol Allergy Clin North Am 27: 389-413.

50. Checkley AM, Chiodini PL, Dockrell DH, Bates I, Thwaites GE, et al (2010) Eosinophilia in returning travelers and migrants from tropics: UK recommendations for investigation and initial management. $J$ Infect 60: 1-20.

51. Ross AG, Vickers D, Olds GR, Shah SM, McManus DP (2007) Katayama syndrome. Lancet Infect Dis 7: 218-224. [Crossref]

52. Doenhoff MJ, Pica-Mattoccia L (2006). Praziquantel for the treatment of schistosomiasis: its use for control in areas with endemic disease and prospects for drugs resistant. Expert Rev Anti Infect Ther 4: 199-210.
53. Obara A, Nakamura-Uchiyama F, Hiromatsu K, Nawa Y (2004) Paragonimiasis cases recently found among immigrants in Japan. Inter Med 43: 388-392.

54. Fürst T, Keiser J, Utzinger J (2012) Global burden of human food-borne trematodiasis a systematic review and meta-analysis. Lancet Infect Dis 12: 210-221.

55. O'Conell EM, Nutmann TB (2015) Eosinophilia in infectious diseases. Immunmol Allergy Clin North Am 36: 493-522.

56. Vijayan VK (2007) Tropical pulmonary eosinophilia: pathogenesis, diagnosis and management. Curr Opin Pul Med 13: 428-433.

57. Mullerpattan JB, Udwadia ZF, Udwadia FE (2012) Tropical pulmonary eosinophilia; a review. Indian J Med Res 183: 295-302.

58. Taylor MJ, Hoerauf A, Bockarie M (2010) Lymphatic filariasis and onchocerciasis Lancet 376: 1175-1185.

59. Junghanss T, da Silva AM, Horton J, Chiodini PL, Brunetti E (2008) Clinica management of cystic echinococcosis: state of the art, problems and perspectives. $\mathrm{Am}$ J Trop Med Hyg 79: 301-311.

60. Moro P, Schantz PM (2009) Echinococcosis: a review. Int J Infect Dis 13: 125-133. [Crossref]

61. Saidini S, Othman Noordin R (2019) Update on laboratory diagnosis amoebiasis. Eur J Clin Microbiol Infect Dis 38: 15-38.

62. Shirley DT, Farr L, Watanabe K, Moonah S (2018) A Review of the Global Burden, New Diagnostics, and Current Therapeutics for Amebiasis. Open Forum Infect Dis 5: ofy161. [Crossref]

63. Anwar A, Khan NA, Siddiqui R (2018) Combating Acanthoamoeba spp. Cysts: what are the options? Parasit Vector 11:26.

64. Jourdan PM, Lamberton PHL, Fenwick A, Addiss DG (2018) Soil-transmitted helminth infections. Lancet 391: 252-265.

65. Smith H, Holland C, Taylor M, Magnaval JF, Schantz P, et al (2009) How common is human toxocariasis? Toward standardizing our knowledge. Trends Parasitol 25: 182 188

66. Stürchler D, Schubarth P, Gualzata M, Gottstein B, Oettli A (1989) Thiabendazole vs albendazole in treatment of toxocariasis: a clinical trial. Ann Trop Med Parasitol 83 . 473-478. [Crossref]

67. Ma G, Holland CV, Wang T, Hofmann A, Fan CK, et al. (2018) Human toxocariasis Lancet Infect Dis 18: e14-14e24. [Crossref]

68. GarcÃa HH, GonzÃ $\tilde{A}_{l}$ lez AE, Del Brutto OH, Tsang VC, Llanos-Zavalaga F, et al (2007). Cysticerosis working group in Peru. Strategies for the elimination of taeniasis/ cysticerosis. J Neurol Sci 262: 153-157.

69. Mirdha BR, Samantray JC (2002) Hymenolepis nana: a common cause of paediatric diarrhoea in urban slum dwellers in India. J Trop Pediatr 48: 331-334. [Crossref]

70. Keiser J, Ultzinger J (2008) Efficacy of current drugs against soil-transmitted helminth infections: systematic review and meta-analysis. J Am Med Assoc 299: 1937-1948.

71. Shimoni Z, Klein Z, Weiner P, Assous MV, Froom P (2007) The use of prednisone in the treatment of trichinellosis. Isr Med Assoc J 9: 537-539. [Crossref]

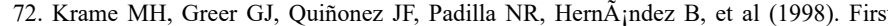
report outbreak of abdominal angiostrongyliasis. Clin Infect Dis 26: 365-372.

73. Parish JM, Blair JE (2008) Coccidioidomycosis. Mayo Clin Proc 83: 343-348 [Crossref]

74. Benedict K, Beer KD (2019) Histoplasmosis-related healthcare use, diagnosis and treatment in a commercially insured population, United States. Clin Infect Dis.

75. Di Mango AL, Zanetti G, Penha D, Menna Barreto M, Marchiori E (2019). Endemic pulmonary fungal diseases in immunocompetent patients: an emphasis in thoracic imaging. Expert Rev Respir Med 13: 263-277.

76. Trinh SA, Echenique IA, Penugonda S, Angarone MP (2018) Safety and efficacy of chronic suppressive azole therapy for endemic fungal infections in solid organ transplant recipient. Transpl Infect Dis 20: e12963.

77. Mecoli CA, Saylor D, Gelber AC, Christopher-Stine L (2017) Pneumocystis jirovec pneumonia in rheumatic disease: a 20 -year single- centre experience. Clin Exp Rheumatol 35: 671-673.

78. Langevin B, Saleh M (2016) Radiological presentation of Pneumocystis jiroveci pneumonia mimicking bacterial pneumonia. BMJ Case Rep. 
79. Liebling M, Rubio E, Ie S (2015) Prophylaxis for Pneumocystis jiroveci pneumonia: is it a necessity in pulmonary patients on high-dose, chronic corticosteroid therapy without AIDS? Expert Rev Respir Med 9: 171-181.

80. Castañeda E, Lizarazo J (2012) A protocol for the study and management of patients with cryptococcosis. Infectio 16: 123-125.

81. Perfect JR, Dismukes WE, Dromer F, Goldman DL, Graybill JR, et al (2010) Clinical practice guidelines for the management of cryptococcal disease: 2010 update by the Infectious Diseases Society of America. Clin Infect Dis 50: 291-322.

82. Molly SF, Kanyama C, Heyderman RS, Loyse A, Kouanfack C, et al (2018). Antifungal combination for treatment of cryptococcal meningitis in Africa. N Engl J Med 378: 1004-1017.

83. Simmons RP, Dudzinski DM, Shepard JO, Hurtado RM, Coffey KC (2019) Case 162019: A 53-Year-Old Man with Cough and Eosinophilia. N Engl J Med 380: 2052 2059. [Crossref]

84. Layden JE, Ghianai I, Pray I, Kimball A, Layer M, et al (2019). Pulmonary illness related to E-cigarette use in Illinois and Wisconsin-Preliminary report. $N$ Engl J Med.

85. Butt YM, Smith ML, Tazelaar HD, Vaszar LT, Swanson KL, et al. (2019) Pathology of Vaping-Associated Lung Injury. $N$ Engl J Med 381: 1780-1781. [Crossref]

86. Watts R, Lane S, Hanslik T, Hauser T, Hellmich B, et al (2007). Development and validation of a consensus methodology for the classification of the ANCA-associated vasculitides and polyarteritis nodosa for epidemiological studies. Ann Rheum Dis 66: 222-227.

87. Guellec D, Milin M, Cornec D, Tobon GJ, Marhadour T, et al (2015). Eosinophilia predicts poor clinical outcomes in recent outcomes in recent-onset arthritis: result of the ESPOIR cohort. RMD open 1: $\mathrm{e} 000070$.

88. Pinal-Fernández I, Selva-O'Callaghan A, Grau JM (2014) Diagnosis and classification of eosinophilic fasciitis. Autoimmun Rev 13: 379-382.

89. Agarwal R, Chakrabarti A, Shah A, Gupta D, Meis JF, et al (2013). Allergic bronchopulmonary aspergillosis: review of literature and proposal a new diagnostic and classification criteria. Clin Exp Allergy 43: 850-873.

90. Alvarado A (2019) Differences, similarities and controversies between bronchial asthma and chronic obstructive pulmonary disease. Clin Res Trials 5: 1-12.

91. Esteban-Gorgojo I, Antolin-Amérigo D, DomÃnguez Ortega J, Quirce S (2018). Noneosinophilic asthma: current perspectives. J Asthma Allergy 11: 267-281.

92. Ortega HG, Liu ML, Pavord ID, Bruselle GG, FitzGerald JM, et al (2014) Mepolizumab treatment in patients with severe eosinophilic asthma 371: 1198-1207.

93. Chung KF, Wenzel SE, Brozek JL, Bush A, Castro M, et al. (2014) International ERS ATS guidelines on definition, evaluation and treatment of severe asthma. Eur Respir J 43: 343-373. [Crossref]

94. Barnes PJ (2017) Cellular and molecular mechanisms of asthma and COPD. Clin Sci (Lond) 131: 1541-1558. [Crossref]

95. Postma DS, Rabe KF (2015) The Asthma-COPD Overlap Syndrome. N Engl J Med 373: 1241-1249. [Crossref]

96. GINA (2019) Global Strategy for Asthma Management and Prevention. Global Initiative for Asthma.

97. Nathan RA, Thompson PJ, Price D, Fabbri ML, Salvi S, et al (2015). Taking aim at asthma around the world: global result of Asthma Insight and Management survey in the Asian-Pacific region, Latin America, Europe, Canada, and the United States. $J$ Allergy Clin Immunol Pract 3: 734.e5-e742.e5.

98. O'Byrne PM, FitzGerald JM, Bateman ED, Barnes PJ, Zhong N, et al (2018). Inhaled combined budesonide-formoterol as needed in mild asthma. N Engl J Med 378: 18651876.

99. Bateman ED, Reddel HK, O’Byrne PM, Barnes PJ, Zhong N, et al (2018). As-needed budesonide-formoterol versus maintenance budesonide in mild asthma. $N$ Engl J Med 378: $1877-1887$

100. Beasley R, Holliday M, Reddel HK, Braithwaite I, Ebmeier S1, et al. (2019) Controlled Trial of Budesonide-Formoterol as Needed for Mild Asthma. $N$ Engl J Med 380: 2020-2030. [Crossref]
101. Lazarus SC, Krishnan JA, King TS, Lang JE, Blake KV, et al. (2019) Mometasone or Tiotropium in Mild Asthma with a Low Sputum Eosinophil Level. $N$ Engl J Med 380: 2009-2019. [Crossref]

102. Price DB, Rigazio A, Campbell JD, Bleecker ER, Corrigan CJ, et al (2015). Blood eosinophilia count and prospective annual asthma disease burden: UK cohort study. Lancet Respir Med 3: 849-858.

103. Castro M, Zahgrilli J, Weschsler ME, Bateman ED, Bruselle GG, et al (2015) Reslizumab for inadequately controlled asthma with elevated eosinophil counts: results from two multicenter, parallel, double-blind, randomized, placebo-controlled phase 3 trials. Lancet Respir Med 3: 355-360.

104. Fajt ML, Wenzel SE (2017) Development of New Therapies for Severe Asthma Allergy Asthma Immunol Res 9: 3-14. [Crossref]

105. Wenzel S, Ford L, Pearlman D, Spector S, Sher L, et al. (2013) Dupilumab in persistent asthma with elevated eosinophil levels. $N$ Engl J Med 368: 2455-2466. [Crossref]

106. Wenzel S, Castro M, Corren J, Maspero J, Wang L, et al (2016). Dupilumab efficacy and safety in adult with uncontrolled persistent asthma despite use of medium-to high-dose inhaled corticosteroids plus long acting Beta 2-agonist: a randomized, double placebo-controlled pivotal phase $2 \mathrm{~b}$ dose-ranging trial. Lancet 388: 31-44.

107. Hopkins C (2019) Chronic Rhinosinusitis with Nasal Polyps. N Engl J Med 381 55-63. [Crossref]

108. GOLD (2019) Global Strategy for the Diagnosis, Management and Prevention of COPD. Global Initiative for Chronic Obstructive Pulmonary Disease.

109. 109. GINA (2019). Diagnosis of Disease of Chronic Airflow Limitation: Asthma, COPD and Asthma-COPD Overlap (ACO). Global Initiative for Asthma.

110. Mirza S, Clay RD, Koslow MA, Scanlon PD (2018) COPD Guidelines: A Review of the 2018 GOLD Report. Mayo Clin Proc 93: 1488-1502. [Crossref]

111. McDonald CF (2017) Eosinophil Biology in COPD. N Engl J Med 377: 1680-1682 [Crossref]

112. Pizzichiani E, Pizzichiani MMM, Gibsoin P, Parameswarank, Gleich GJ, et al (1998) Sputum eosinophilia predicts benefits from prednisone in smokers with chronic obstructive bronchitis. Am J Respir Crit Care Med 158: 1511-1517.

113. Brightling CE, Monteiro W, Ward R, Parker D, Morgan MD, et al (2000). Sputum eosinophilia and short-term response to prednisolone in chronic obstructive pulmonary disease: a randomized controlled trial. Lancet 28: 1480-1485.

114. Pascoe S, Locantore N, Dransfield MT, Barnes NC, Pavord ID (2015). Blood eosinophil counts, exacerbations and response to the addition of inhaled fluticasone furoate to vilanterol in patients with chronic obstructive pulmonary disease: a secondary analysis of data from two parallel randomized controlled trials. Lancet Respir Med 3: 435-442.

115. Pavord ID, Chanez P, Criner GJ, Kerstjens HAM, Kor S, et al (2017). Mepolizumab for eosinophilic chronic obstructive pulmonary disease. Epub 377: 1613-1619.

116. Dasgupta A, Kjarsgaard M, Capaldi D, Radford K, Aleman F, et al (2017). A pilot randomized clinical trial of mepolizumab in COPD with eosinophilic bronchitis. Eur Respir J 49: 1602486.

117. Criner GJ, Celli BR, Brightling CE, Agusti A, Papi A, et al. (2019) Benralizumab for the Prevention of COPD Exacerbations. N Engl J Med 381: 1023-1034. [Crossref]

118. Reed CC, Dellon ES (2019) Eosinophilic Esophagitis. Med Clin North Am 103: 2942. [Crossref]

119. Gómez-Aldana A, Jaramillo-Santos M, Delgado A, Jaramillo C, L $\tilde{A}^{\circ}$ quez-Mindiola A (2019). Eosinophilic esophagitis: current concepts in diagnosis and treatment. World J Gastroenterol 25: 4598-4613.

120. Flaherty KF, Wells AV, Cottin V, Devaraj A, Walsh SLE, et al (2019). Nintedanib in progressive fibrosis interstitial lung disease. $N$ Engl J Med.

121. Rushworth RL, Torpy DJ, Falhammar H (2019) Adrenal Crisis. N Engl J Med 381: 852-861. [Crossref]

Copyright: (C2020 Alvarado A. This is an open-access article distributed under the terms of the Creative Commons Attribution License, which permits unrestricted use, distribution, and reproduction in any medium, provided the original author and source are credited. 